\title{
MODELING TECHNIQUES IN MOMS AND CHILDREN ON THE SUCCESS OF TOILET TRAINING AMONG TODDLER AGE CHILDREN
}

\author{
Asbath Said ${ }^{1}$, Nurdin ${ }^{2}$ \\ ${ }^{1,2}$ College of Health Sciences Mandala Waluya Kendari, Southeast Sulawesi, Indonesia
}

Corresponding Author : Asbath Said

Email : asbath.mw@gmail.com

\begin{abstract}
Background: The ability of children in activities related to toilets that take care of an inheritance, but something that must always be remembered and taught. To teach skills for this training, it takes the right technique or method so that it is easy to connect with children. One such technique is modeling techniques. The research objective was to determine the effect of modeling techniques on mothers and children on the success of toilet training in Toodler-aged children at PAUD AFI, Konawe Regency.

Methods: Using quantitative methods through this type of pre-experimental research with a one-group approach pretest-posttest design with simple random sampling means that the sample is 30 children aged.

Result: The results of the Paired T-Test explain the effect of modeling techniques on mothers and children on toilet training for toddlers in PAUD AFI, Konawe Regency $(\mathrm{p}=0.000)$. .

Conclusion: The use of modeling techniques in mothers and children must prepare and build from an early age for children where parents can teach children of age-related to the good toilet so that they can toilet training for children toddler.
\end{abstract}

Key words: Modeling techniques, toilet training, toddler 


\section{INTRODUCTION}

Growth and development are two different terms, but they are inseparable and independent (1). According to Supartini, children are individuals who still depend on adults and their environment, meaning they need an environment that can facilitate the fulfillment of children's needs (2). Nursalam explained that growth is an increase in the physical size and structure of a person's body due to an increase in the number and size of cells quantitatively, such as an increase in body weight, height, and head circumference. Development is defined as an increase in the maturity of the functions of each body and is qualitative, such as the child's ability to lie on his stomach, sit, walk, talk, pick up objects around him, as well as the emotional and emotional maturity of the child (3).

According to Wong, the development of children consists of the prenatal period (from conception to 40 weeks of gestation), the infant period (from birth to 12 months of age), the early childhood period 1 year to 6 years of age), the middle childhood period ( ages 6 to 11-12), and late childhood (ages 11-12 to 18 years). The early childhood period consists of the toddler, namely the age of children 1 to 3 years, and the preschool period, which is between 3 to 6 years (3). According to Freud regarding the psychosexual development of children this age is in the anal phase where the child's pleasure lies in the anal. Children like to hold their feces, even playing with their feces as they wish. Thus, toilet training is the right time to do this during this period (4). Usually, as the child can walk, the two sphincters are increasingly able to control the urge to urinate and defecation, so this phase is the right time to teach children toilet training. To assess the failure of toilet training can be seen at preschool age, where children should be able to urinate and defecate without the help of other people. One of the factors causing the independence of children to defecate and not urinate in the toilet is the use of diapers (5).

\section{METHOD}

This study used a pre-experimental design through a one-group pretest-posttest design approach with a total sample of 30 children aged toddler based on inclusion criteria. The sample was taken using a simple random sampling technique. This research was conducted at PAUD AFI Konawe Regency using bivariate analysis, namely the Paired T-Test.

\section{RESULT}

Table 1.Distribution of Respondents by Gender, Age, Child Toileting Pre-Test and Post-Test for Children in PAUD AFI, Konawe Regency

\begin{tabular}{llcc}
\hline Variable & Category & f & $\%$ \\
\hline Gender & Male & 14 & 46,7 \\
& Female & 16 & 53,3 \\
\hline Age & 2 years & 9 & 30,0 \\
& 3 years & 18 & 60,0 \\
& 4 years & 3 & 10,0 \\
\hline Child & Enough & 5 & 16,7 \\
Toileting Pre & Less & 25 & 83,3 \\
Test & & & \\
\hline Child & Enough & 19 & 63,3 \\
Toileting & Less & 11 & 36,7 \\
Post Test & & & \\
\hline \multicolumn{2}{c}{ Total } & 30 & 100 \\
\hline
\end{tabular}

Table 1 shows that the most respondents based on gender are women as many as 16 respondents $(53.3 \%)$, the most dominant age of the respondents is 3 years old as many as 18 respondents $(60.0 \%)$, the behavior of children's toileting before treatment is known that toileting is dominated by toileting. less than 25 respondents $(83.3 \%)$ and the behavior of children's toileting after treatment it was known that sufficient toileting was 19 respondents $(63.3 \%)$. 
Tabel 2.Effect of modeling techniques on mothers and children on the success of toileting training in toddler uses at PAUD AFI, Konawe Regency

\begin{tabular}{c|c|c|c|c}
\hline No & $\begin{array}{c}\text { Toileting } \\
\text { Test }\end{array}$ & Mean & $\begin{array}{c}\mathbf{t} \\
\text { Count }\end{array}$ & $\begin{array}{c}\boldsymbol{p} \\
\text { Value }\end{array}$ \\
\hline 1 & Pre test & 4,67 & 10,830 & 0,000 \\
2 & Pos test & 8,77 & & \\
\hline
\end{tabular}

Table 2 shows that the mean value at the time of the pre-test was 4.67 and at the post-test was 8.77, the results of the statistical test showed that the p-value $<0.05$, the $t$ value $10.830>$ the $t$ table value 1.734 which means that there is the effect of modeling techniques on mothers and children on the success of toilet training in toddlers.

\section{DISCUSSION}

The results of the post-test research obtained a mean value of 8.77 which means there is an increase in the mean value of the mean pre-test, this indicates that there has been an improvement in children's toileting to be sufficient where sufficient toileting for children is 19 respondents where 18 children already understand that $\mathrm{BAK}$ and $\mathrm{BAB}$ must be in the toilet but there are still 11 respondents who are still lacking in toileting, especially in the part of drying wet body parts that were rinsed after defecating and washing, only 7 people did it from all respondents, likewise for the act of cleaning themselves / wiping properly only 8 respondents from the whole Those who do this are due to other factors that cause this, such as the age of the child who is still a toddler so that it takes time and the participation of parents at home to always guide, direct and get their children to do toileting independently at home, the statistical test results obtained a significant value of $0.000<0,05$. the results of the analysis of the table above also obtained the value of $t$ count $=10.830>1.734$, where $t$ is greater than the value of $t$ table. This shows that there is an effect of using modeling techniques on mothers and children on the success of toilet training for toddlers age children in PAUD AFI, Konawe Regency.

According to Hidayat, the definition of toilet training is an effort to train children to be able to control their urination and defecation. This toilet training can take place in a child's life phase, namely the age of 18 months - 24 months. In the practice of urinating and defecating, children need preparation both physically, psychologically, and intellectually. Through this preparation, it is hoped that the child will be able to control the bowel and urination independently (6). These toilet training skills include the child's ability to be aware of the willingness of BAK and defecating, the child's ability to communicate it, the child's ability to control BAK and defecate correctly in the bathroom (toilet), in the form of the child can resist the urge to defecate until he reaches the toilet and mastery of all a series of behaviors to go to the toilet (going to the bathroom, taking off your pants/skirt and panties, sitting on the toilet and urinating/defecating, cleaning yourself / wiping until it is clean, standing up from the toilet, flushing the toilet until it is clean, drying wet body parts with a rag, put on your underwear and pants/skirt, wash your hands and dry them $(5,7)$.

The success of toilet training depends on the readiness of the child and the family, such as physical readiness, where the child's ability is physically strong and capable. This can be shown that the child can sit or stand so that it makes it easier for children to be trained to defecate and urinate, as well as psychological readiness where the child needs a comfortable atmosphere to be able to control and concentrate in stimulating to defecate or urinate and knowing some parts of the body and function (8). Toilet training is also important in the development of a child's personality because toilet training is the first moral exercise that a child has received and is very influential in subsequent moral development (9). Widayatun explained 
that parents' motivation is influenced by intrinsic factors and extrinsic factors. Intrinsic factors are the impulses that come from within a person, namely in the form of knowledge, attitudes, mental state, and age maturity, while extrinsic factors are in the form of facilities, infrastructure, and the environment (3).

\section{CONCLUSION}

The effect of using modeling techniques on mothers and children on the success of toilet training in toddler age children in PAUD AFI, Konawe Regency. The use of modeling techniques in mothers and children must consider the early introduction and teach children where parents can teach children about good toileting so that the success of toilet training in toddler age children.

\section{REFERENCES}

1. Riyadi, Sujono. (2009). Nursing Care for Children. Yogyakarta: Graha Ilmu.

2. Islaeli, Islaeli, Yati, Mimi, \& Fadmi, Fitri Rachmillah. (2020). The effect of play puzzle therapy on anxiety of children on preschoolers in Kendari City Hospital. Enfermería Clínica, 30, 103-105.

3. Ningsih, Sri Fitdiyah. (2012). The relationship between knowledge and behavior of mothers in implementing toilet training with bedwetting habits in preschool children in RW 02 Babakan Urban Village, Tangerang City.

4. Cahyaningsih, Dwi Sulistyo. (2011). Developmental growth of children and adolescents. Jakarta: TIM.

5. Uyun, Khumrotul, Arifah, Siti, Kp, S, Ke, M, \& Dian Nur, W. (2016). The Relationship between using diapers and toilet training skills for toddlers in Jrahi Pati village. Muhammadiyah Surakarta university.

6. Warlenda, Sherly Vermita, Maharani, Riri, \& Widodo, M Dedi. (2019). Factors Related To The Implementation Of Toilet Training In

\section{3-5 Years Old Children In Paud In} Pekanbaru City In 2017. Menara Ilmu, 13(1).

7. Wantah, Maria J. (2007). PTeaching Discipline and Moral Formation: Jakarta: Ministry of National Education, Directorate General of Higher Education.

8. Hidayat, \& Aziz, Alimul. (2012). Introduction to Child Nursing (Vol. 3). Jakarta Salemba Medika.

9. Suherman. (2000). Child Development Pocket Book. . Jakarta: EGC. 